\title{
MANUFACTURE AND EVALUATION OF A LOCAL SIMPLIFIED POTATO DIGGER
}

\author{
Mahmoud M. A. Ali *
}

ABSTRACT

Filed experiments were carried out to manufacture a simplified potato digger from locally available materials and evaluate its performance under laboratory and field conditions. Digger performance was conducted under four different soil moisture contents (d.b.) of (9, 11, 13 and $15 \%)$ and three different digging depths of (22, 27 and $32 \mathrm{~cm})$. Digging operation was carried out at four different forward speeds of (0.9, 1.6, 2.2 and $2.8 \mathrm{~km} / \mathrm{h})$. Digger performance was evaluated in terms of potato losses, digging efficiency, energy requirements and digging cost. The experimental results reveal to the following:

- The suitable digging depth to dig all potato tubers is $27 \mathrm{~cm}$.

- The optimum soil moisture content suitable for digging potato is $11 \%$.

- The proper forward speed for operating the manufactured potato digger is $2.2 \mathrm{~km} / \mathrm{h}$.

\section{INRODUCTION}

$\mathrm{P}$ otato is one of the most important economical crops in the world and Egypt which participate in the international and national income. The total cultivated area in Egypt are about 200000 feddan yearly producing about 2.06 million $\mathrm{Mg}$ with an average yield of $10.3 \mathrm{Mg} /$ fed according to (Ministry of agriculture, 2005). Mechanical harvesting machines of potatoes are still unused widely in Egypt. Due to the high cost, required for high capacity tractors, small holdings, and irrigation systems all of these factors are significant obstacles to the application of mechanical harvesting in Egypt. In addition, this problem could be solved by manufacturing small machinery, low cost and low power under optimum condition. Maughan and Allam (1986) compared mechanical harvesting of potato with manual methods. They found that the mechanical harvesting reduced the requirements of man.h/Mg by 27.7 \%. Abd El-Magid (1987) developed potato harvester, which can be operated under the optimum parameters to achieve maximum lifting efficiency of $92 \%$ and minimum damage of $2.5 \%$.

\footnotetext{
${ }^{*}$ Assis. Prof. of Agric. Eng. Dept., Fac. of Agric., Zagazig Univ., Egypt.
} 
For the digger: blade width $35 \mathrm{~cm}$, tilt angle $21-23^{\circ}$ and apex angle 30 $35^{\circ}$. For the concave: disk diameter $45 \mathrm{~cm}$, tilt angle $25-29^{\circ}$, disk angle 26-32 and the distance between axes 61-64 cm. For the furrow: tilt angle $75^{\circ}$ and finger spacing $14 \mathrm{~cm}$. Younis (1987) tested one row potato digger mounted on $51.5 \mathrm{~kW}$ (70 hp) tractor in sandy soil at different digging depths and forward speeds. He found that the total losses such as skinned potato and damage by the lifting operation were about $3 \%$ of the total yield compared with 8-14\% for conventional harvesting (Baladi plow). Amin (1990) developed potato harvester having field capacity of $0.31 \mathrm{fed} / \mathrm{h}$, and field efficiency of $91.32 \%$ at forward speed of $2.1 \mathrm{~km} / \mathrm{h}$. Harvesting potato tubers using the developed harvester costed 16.47 L.E/fed, while the traditional methods costed 80 L.E/fed. Mady (1999) indicated that the increasing of digging depth and the decreasing of forward speed reduced the percentage of unlifted roots, bruised roots and cut roots and increased the percentage of lifted roots and undamaged roots. The lowest values of unlifted roots were $3.0 \%$, bruised roots of $5.1 \%$, cut roots of $4.0 \%$ and the highest values of lifted roots $97 \%$, undamaged roots of $90.9 \%$ and digging cost of 44.65(L.E./ton) were obtained at the digging depth of $40 \mathrm{~cm}$ and forward speed of $1.5 \mathrm{~km} / \mathrm{h}$. $\mathrm{He}$ also found that the lowest and highest energy requirements of 66.43 and $187.9 \mathrm{kWh} / \mathrm{fed}$. and the highest and lowest values of cost of 245.28 and 44.65L.E./ton were obtained at digging depth of 25 and $40 \mathrm{~cm}$ and forward speed of 3.6 and $1.5 \mathrm{~km} / \mathrm{h}$, respectively. Afify and Mechail (2000) developed and constructed a simple potato harvester. They found that the optimum forward speed for digging was $4.49 \mathrm{~km} / \mathrm{h}$ to increase the percentage of raised potato to $96.86 \%$, reduce the skin, and cut damage to $1.11 \%$ and missing tubers to $3.14 \%$. They reported that using a box-picker reducing the digging cost to $20 \%$. Abdel-Aal et al. (2002) modified a potato harvester to be suited for Egyptian farms. The optimum engineering parameters for the modified harvester were forward speed of $2.3 \mathrm{~km} / \mathrm{h}$, digger tilt angle of $14^{\circ}$, distance between the blade and elevator chain of $5 \mathrm{~cm}$, chain speed of $(100 \mathrm{rpm}) 2.41 \mathrm{~m} / \mathrm{s}$, riddle speed of $11.16 \mathrm{~m} / \mathrm{s}$, and riddle inclination of $7^{\circ}$. They achieved the highest undamaged, lowest damaged and losses tubers $(87.4 \%, 1.98$ and $10.62 \%$, respectively) under the optimum engineering parameters for the modified 
harvester. Abdel Maksoud et al. (2004) developed a potato digger for harvesting and gathering potato. They recommended that the forward speed was about $2.4 \mathrm{~km} / \mathrm{h}$, penetration angle of $14^{\circ}$, sieve slope of $8^{\circ}$ and operating speed of $12 \mathrm{~m} / \mathrm{s}$ to achieve the highest undamaged with the lowest damage and buried potato. Younis et al. (2006) developed and tested a potato digger at four levels of forward speed $(0.9,1.5,1.9$ and $3.2 \mathrm{~km} / \mathrm{h}$ ), four levels of vibrating amplitude (3, 5, 6 and $10 \mathrm{~mm}$ ) and five levels of vibrating frequency $(400,600,800,1000$ and $1200 \mathrm{rpm})$. They found that the developed digger succeed to operate with lower power tractors thus the harvesting cost was reduced by $28.5 \%$.Ibrahim, et al. (2008) developed a multi purpose digger for harvesting root crops (potato and peanut). The developed digger was tested at three levels of forward speed $(1.8,2$ and $2.6 \mathrm{~km} / \mathrm{h})$ for potato, $(1.4,1.8$ and $2.3 \mathrm{~km} / \mathrm{h})$ for peanut and three different tilt angles $\left(12^{\circ}, 18^{\circ}\right.$ and $\left.24^{\circ}\right)$. From the obtained results, the proper conditions to operate the developed digger were $22 \mathrm{~cm}$ harvesting depth, $2.6 \mathrm{~km} / \mathrm{h}$ forward speed and $18^{\circ}$ tilt angle for potato crop. The cost of harvesting using the digger was 91.55 L.E. /fed, for potato and 101.24 L.E. /fed for peanut. The objectives of this study are to:

- Manufacture of a local potato digger to suit small Egyptian farms.

- Select the optimum conditions for operating the manufactured potato digger (forward speed, soil moisture content and digging depths) under Egyptian conditions.

\section{MATERIALS AND METHOD}

The main experiments were carried out at Al-Khattara farm, El-Sharkia governorate through the season of 2012. The mechanical analysis of the experimental soil was classified as a sandy soil table (1).

Table (1): Mechanical analysis of the experimental soil.

\begin{tabular}{|c|c|c|c|c|}
\hline Depth,cm & $(\%)$ Clay & $(\%)$ Silt & $(\%)$ Sand & (Soil type) \\
\hline $0-35$ & 4.1 & 8.7 & 87.2 & Sandy \\
\hline
\end{tabular}

\section{MATERIALS:}

\section{The used crop:}

The experimented area was planted manually with spunta potato variety. Field experiments with tubers rate of $1500 \mathrm{~kg} / \mathrm{fed}, 100 \mathrm{~cm}$ row spacing and about $30 \mathrm{~cm}$ between hills in the same row. 


\section{The used tractor:}

A Kubota tractor model (L 285) (4WD), made in Japan, engine power of $35 \mathrm{hp}(25.73 \mathrm{~kW})$ direct injection, water cooled, 4 cycles diesel, 4 cylinders, engine rated speed $2600 \mathrm{rpm}$, mass $1230 \mathrm{~kg}$ was used to operate the manufacture digger in field experiments.

\section{The manufactured potato digger:}

The manufactured potato digger was constructed from local materials at the workshop of Agricultural Engineering Department, faculty of agriculture, Zagazig University to overcome the problems appearing at using the traditional method for digging potato (manually with hoe), which consumed more time, effort and cost. The manufactured potato digger is of $178 \mathrm{~cm}$ length, $130 \mathrm{~cm}$ width and $82 \mathrm{~cm}$ height. The manufactured potato digger is shown in Photo (1) and Fig. (1). The digger consists of the main rectangular frame, digging flat blade, separating chain and the transmission system.

\section{- The main rectangular frame:}

The main rectangular frame is made of iron sheet steel. The frame is of $128 \mathrm{~cm}$ length, $90 \mathrm{~cm}$ width, 46 and $36 \mathrm{~cm}$ front and rear height, respectively and $0.5 \mathrm{~cm}$ thickness. The frame includes elements to fix gearbox, digging flat blade, separating chain, the transmission system and hitching unit. Two tires wheel $30 \mathrm{~cm}$ diameters and $8 \mathrm{~cm}$ thickness carry the frame. The two wheels were adjusted to be suited for the distance between the furrows.

\section{- Digging flat blade:}

Digging blade is made of iron steel $80 \mathrm{~cm}$ length, $30 \mathrm{~cm}$ width and 1.2 cm thickness.

\section{- Separating chain:}

The separating chain is of $140 \mathrm{~cm}$ length, $78 \mathrm{~cm}$ width. The chain web consists of straight bars of steel $1 \mathrm{~cm}$ diameter and $78 \mathrm{~cm}$ length. The distance between bars is $4 \mathrm{~cm}$ to allow soil to pass through back to the field in order to accomplish the operation of cleaning potato. The chain was operated by means of sprocket and chain powered from the tractor P.T.O. with an average speed of $125 \mathrm{rpm}(1.31 \mathrm{~m} / \mathrm{s})$. 


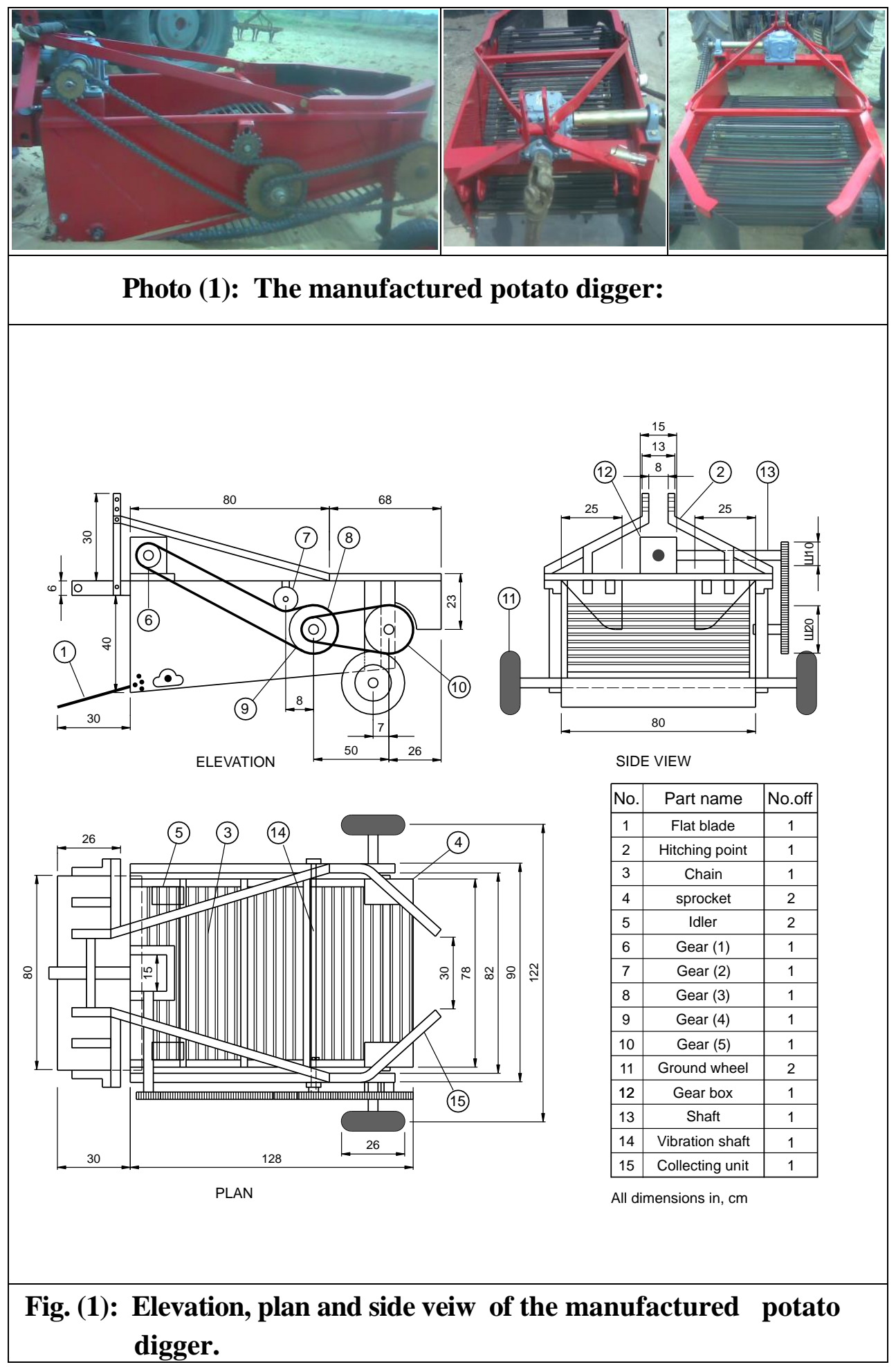




\section{- The transmission system:}

The transmission system transmits power by gearbox powered from the tractor P.T.O. through a universal unit. The power is transmitted from the gearbox to chain by five gears in two groups. The first group consists of three gears of 10, 10 to $20 \mathrm{~cm}$ diameters and the second group consists of two gears of 10 to $20 \mathrm{~cm}$ diameters. The overall specifications of the manufactured potato digger is shown in Table (2).

Table (2): Overall specifications of the manufactured potato digger.

\begin{tabular}{|l|l|l|l|l|}
\hline Potato digger & Main frame & Separating chain & Blade dimensions & Hiching point \\
\hline Length: $178 \mathrm{~cm}$ & Length: $128 \mathrm{~cm}$ & Length:140 cm & Length: $80 \mathrm{~cm}$ & No. Off : $3 \mathrm{point}$ \\
\hline Width: $130 \mathrm{~cm}$ & Width: $90 \mathrm{~cm}$ & Width: $78 \mathrm{~cm}$ & Width: $30 \mathrm{~cm}$ & Width $: 80 \mathrm{~cm}$ \\
\hline Height: $78 \mathrm{~cm}$ & Front height: $46 \mathrm{~cm}$ & bars length $: 1 \mathrm{~cm}$ & Thickness: $1.2 \mathrm{~cm}$ & Hight : $26 \mathrm{~cm}$ \\
\hline Mass: $232 \mathrm{~kg}$ & Rear height: $36 \mathrm{~cm}$ & & & \\
\hline
\end{tabular}

\section{METHODS:}

The experimental area was about four feddans planted manually with spunta potato variety with tubers rate of $1500 \mathrm{~kg} / \mathrm{fed}$. This area was divided into four equal plots (one feddan each) $(100 \times 42 \mathrm{~m}$ each) for different soil moisture contents (d.b.) of $(9,11,13$ and $15 \%)$. Each plot was classified into three equal subplots $(100 \times 14 \mathrm{~m}$ each $)$ for three different digging depths of $(22,27$ and $32 \mathrm{~cm})$. Digging operation was carried out at four different forward speeds of $(0.9,1.6,2.2$ and 2.8 $\mathrm{km} / \mathrm{h}$ ). All experiments were carried out under recommended share angle of $14^{\circ}$ and chain speed of $125 \mathrm{rpm}(1.31 \mathrm{~m} / \mathrm{s})$.

\section{- Measurements:}

\section{- Soil moisture content(dry bases):}

Soil moisture content can be determined using the following formula:

$$
\text { M.C. }=\frac{m_{1}-m_{2}}{m_{2}} \times 100,
$$

Where:

M.C. = Moisture content, $\%$.

$m_{l}=$ Sample mass before drying, $\mathrm{g}$.

$m_{2}=$ Sample mass after drying, $\mathrm{g}$. 


\section{- Actual field capacity:}

Actual field capacity was the actual average time consumed during digging operation (lost time + productive time). It can be determined from the following equation, (Keppner et al. 1982):

Where:-

$$
F . C_{a c t}=\frac{60}{T u+T i}, \quad(\mathrm{fed} / \mathrm{h})
$$

$F \cdot C_{a c t}=$ The actual field capacity of the potato digger.

$T u=$ The utilization time per feddan in minutes.

$T i=$ The summation of lost time per feddan in minutes.

\section{- Field efficiency:}

Field efficiency is calculated by using the values of the theoretical field capacity and actual field capacity rates as, (Keppner et al. 1982):

Where:

$$
\eta_{f}=\frac{F \cdot C_{a c t}}{F \cdot C_{t h}} \times 100
$$

$\eta_{f}=$ Field efficiency, $\%$.

F. $C_{t h}=$ Theoretical field capacity of the potato digger.

\section{- Technical examination of potato tubers:}

The technical examination of potato tubers was determined after cleaning tubers from the sand to classify the tubers in groups. Five random samples of tubers were collected and weighted for each treatment. Each sample was divided into five groups of tubers namely: lifted, un-lifted, bruised, cut and undameaged.

\section{- Lifted tubers:}

Lifted tubers were determined by weighting the tubers lifted by the manufactured digger share, collected from the area of $10 \mathrm{~m} 2$ and calculated the yield of lifted tubers from one feddan using the following equation:

$$
W_{Y}=\frac{4200 \times W_{L}}{A \times 1000}, M g / f e d .
$$

The lifted tubers percentage $\left(L_{t} \%\right)$ was calculated using the following equation :

$$
L_{t}=\frac{W_{L}}{W_{t}} \times 100
$$


Where:

$W_{Y}=$ The yield of lifted tubers from one feddan, $\mathrm{Mg} / \mathrm{fed}$.

$W_{L}=$ Mass of lifted tubers from the experimetal area, $\mathrm{kg}$.

$A=$ Experemental area, $\left(10 \mathrm{~m}^{2}\right)$.

$W_{t}=$ Total mass of lifted and unlifted tubers the experimetal area, $\mathrm{kg}$.

\section{- Total losses:}

The total losses including unlifted, bruised and cut tubers percentage $\left(U L_{t} \%, B_{t} \%\right.$ and $\left.C_{t} \%\right)$ were calculated as follow:

$$
\begin{aligned}
& \text { Unlifted, } \% \text { or } U L_{t}=\frac{W_{U L}}{W_{t}} \times 100 \ldots . \\
& \text { Bruised, } \% \text { or } B_{t} \%=\frac{W_{1}}{W_{t}} \times 100 \\
& \text { Cut, \% or } C_{t} \%=\frac{W_{2}}{W_{t}} \times 100
\end{aligned}
$$

Where:

$W_{U L}=$ Mass of unlifted tubers from the experimetal area, $\mathrm{kg}$.

$W_{t}=$ Total mass of tubers in the sample, $\mathrm{kg}$.

$W_{l}=$ Mass of bruised tubers, $\mathrm{kg}$.

$W_{2}=$ Mass of cut tubers, $\mathrm{kg}$.

Damaged can be calculated using the following equation:

$$
\text { Damaged, } \%=\text { Bruised, } \%+C u t, \%
$$

Total losses can be calculated using the following equation:

Total losses, $\%=$ Unlifted,$\%+$ Damaged $\%$

\section{- Digging efficiency:}

Digging efficiency is the mass of undamaged potato tubers raised over the soil surface by the manufacture digger share and calculated using the following equation:

$$
\text { D.E. } \%=\frac{\mathrm{W}_{L}-\left(W_{1}+W_{2}\right)}{W_{t}} \times 100 \text {. }
$$

\section{- Energy requirements:}

To estimate the engine power during digging operation, the decrease in fuel level in fuel tank accurately measuring immediately after each 
treatment. The following formula was used to estimate the engine power (Hunt, 1983):-

$$
E P=\left[f . c .(1 / 3600) P E \times L . C . V \times 427 \times \eta_{t h b} \times \eta_{m} \times 1 / 75 \times 1 / 1.36\right], k W . .
$$

Solving equation (12), the engine power can be calculated as following:

Engine power $($ Diesel $)=3.16 f . c ., k W$..

Where:-

$f . c=$ Fuel consumption, $(l / \mathrm{h})$.

$\rho E=$ Density of fuel, $(\mathrm{kg} / l)$, (for Gas oil $=0.85)$.

L.C.V = Calorific value of fuel, $(11.000 \mathrm{k} . \mathrm{cal} / \mathrm{kg})$.

$\eta_{t h b}=$ Thermal efficiency of the engine, $(35 \%$ for Diesel engine).

$427=$ Thermo-mechanical equivalent, $(\mathrm{kg} \cdot \mathrm{m} / \mathrm{k} \cdot \mathrm{Cal})$.

$\eta_{m}=$ Mechanical efficiency of the engine, (80\% for Diesel engines).

So, the energy can be calculated as following:

$$
\text { Energy requirement }=\frac{\text { Engine power },(k W)}{\text { Actual field capacity }(\text { fed } / h)}, k W . h / \text { fed ...(14) }
$$

\section{- Digging cost:}

The total cost of digging operation was estimated using the following equation. (Awady et. al, 1982):

Where:-

$$
\text { Operating } \cos t=\frac{(\text { potato digger }+ \text { tractor }) \cos t(\text { L.E. } / h)}{\text { Actual field capacity }(\text { fed } / h)}, \quad(\text { L.E } / \text { fed }) \text {. }
$$

Both the potato digger and tractor cost was determined by using the following equation (Awady, 1978):

$$
C=\frac{P}{h}\left(\frac{1}{a}+\frac{i}{2}+t+r\right)+(1.2 W \cdot S . F)+\frac{m}{144}
$$

Where:-

$C=$ Hourly cost, L.E/h.

$h=$ Yearly working hours, h/year.

$i=$ Interest rate/year.

$t=$ Taxes, over heads ratio.

$m=$ The monthly average wage, L.E

$W=$ Engine power, $\mathrm{hp}$.
$P=$ Price of machine, L.E

$a=$ Life expectancy of the machine, $\mathrm{h}$.

$F=$ Fuel price, L.E/l.

$r=$ Repairs and maintenance ratio.

$0.9=$ Factor accounting for lubrications .

$S=$ Specific fuel consumption, $l / h p . h$.

$144=$ Reasonable estimation of monthly working hours. 
Criterion cost can be determined using the following equation:

Criterion cost $($ L.E/fed $)=$ Operational cost + Losses cost .

\section{RESULTS AND DISCUSSION}

Discussion will cover the results obtained under the following headings:

\section{1- Field capacity and efficiency:}

a-Effect of digger forward speed on field capacity and efficiency:

Results in Fig (2) show a remarkable drop in the field efficiency with a consequent sharp rise in actual field capacity as the forward speed increased. Results show that increasing forward speed from 0.9 to 2.8 $\mathrm{km} / \mathrm{h}$ leads to increase actual field capacity values from 0.1876 to $0.541 \mathrm{fed} / \mathrm{h}$, from 0.184 to $0.53 \mathrm{fed} / \mathrm{h}$ and from 0.173 to $0.502 \mathrm{fed} / \mathrm{h}$ under digging depths of 22,27 and $32 \mathrm{~cm}$, respectively. On the other hand, increasing forward speed from 0.9 to $2.8, \mathrm{~km} / \mathrm{h}$ leads to decrease field efficiency values from 97.2 to $90.16 \%$, from 95.34 to $88.33 \%$ and from 89.63 to $83.66 \%$, under the same previous conditions at soil moisture content of $11 \%$. The major reason for the reduction in field efficiency by increasing forward speed is due to the less theoretical time consumed in comparison with the other items of time losses.

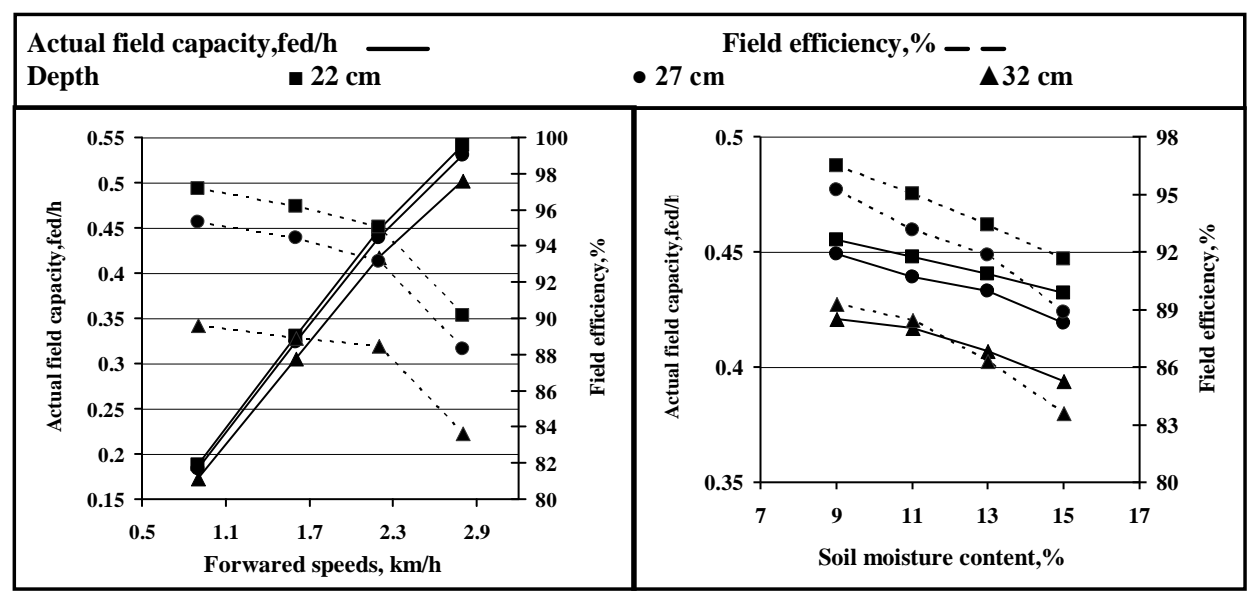

Fig (2): Effect of digger forward speed on field capacity and field efficiency under different digging depths, (S.M.C. =11 \%).

\section{b-Effect of soil moisture content on field capacity and efficiency:}

Results in Fig (2) show that increasing soil moisture content from 9 to 15 $\%$ leads to decrease actual field capacity values from 0.455 to 0.432 
fed/h, from 0.449 to $0.419 \mathrm{fed} / \mathrm{h}$ and from 0.421 to $0.394 \mathrm{fed} / \mathrm{h}$ under digging depths of 22,27 and $32 \mathrm{~cm}$, respectively. Also, increasing soil moisture content from 9 to $15 \%$ leads to decrease field efficiency values from 96.51 to $91.64 \%$, from 95.24 to $88.88 \%$ and from 89.3 to $83.58 \%$ under digging depths of 22,27 and $32 \mathrm{~cm}$, respectively.

\section{Lifted, un-lifted, cut and bruised potato tubers:}

a- Effect of digger forward speed on Lifted, un-lifted, cut and bruised potato tubers:

Results in Fig (3) show the effect of forward speed on lifted, un-lifted, cut and bruised tubers. Concerning increasing forward speed from 0.9 to $2.8 \mathrm{~km} / \mathrm{h}$, decreased the lifted tubers values from 94.6 to $90.7 \%$, from 98.3 to $94.3 \%$ and from 99.2 to $95.7 \%$ under digging depths of 22,27 and $32 \mathrm{~cm}$, respectively. While, increasing forward speed from 0.9 to 2.8 $\mathrm{km} / \mathrm{h}$, increased the un-lifted tubers from 5.4 to $9.3 \%$, from 1.7 to $5.7 \%$ and from 0.8 to $4.3 \%$ under the same previous conditions. Relating to the effect of forward speed on cut and bruised tubers. Fig.(3) shows that increasing forward speed, decreased cut and bruised tubers up to 2.2 $\mathrm{km} / \mathrm{h}$. Any further forward speed increase, up to $2.8 \mathrm{~km} / \mathrm{h}$ increased cut and bruised tubers. Increasing forward speed from 0.9 to $2.8 \mathrm{~km} / \mathrm{h}$, decreased cut tubers from 4.39 to $3.9 \%$, from 3.33 to $2.9 \%$ and from

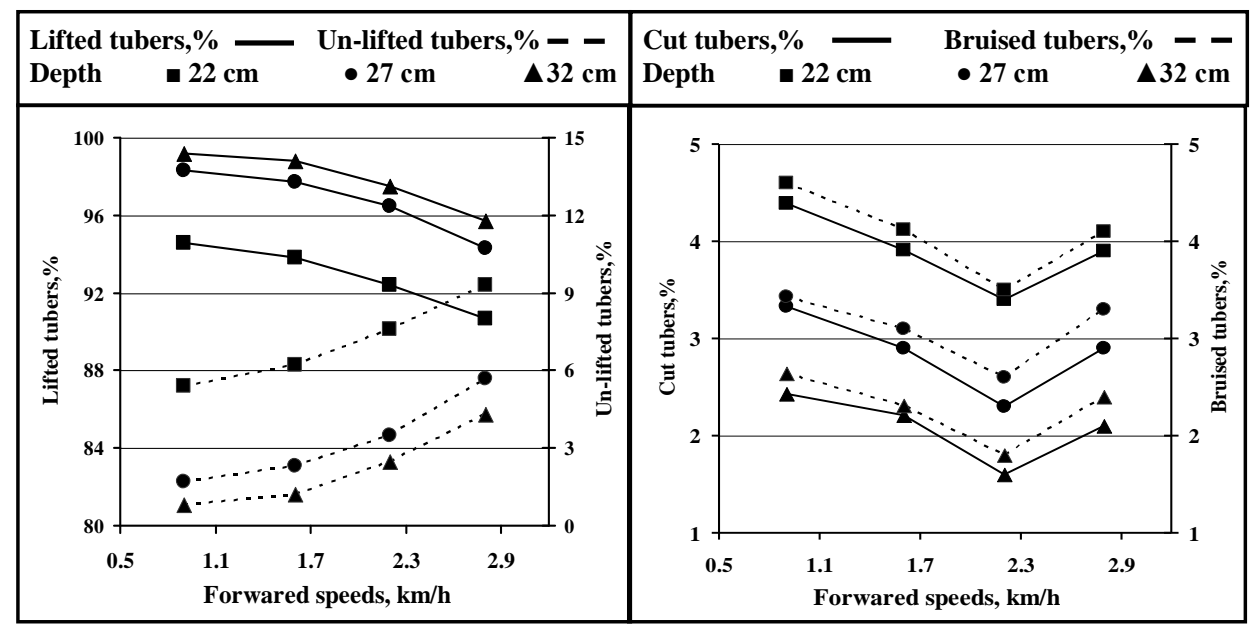

Fig (3): Effect of digger forward speed on mass of lifted, un-lifted, cut and bruised tubers under different digging depths, (S. M. C. $=11 \%$ ). 
2.43 to $2.1 \%$ under digging depths of 22,27 and $32 \mathrm{~cm}$, respectively. Also, increasing forward speed from 0.9 to $2.8 \mathrm{~km} / \mathrm{h}$, decreased bruised tubers from 4.6 to $4.1 \%$, from 3.43 to $3.3 \%$ and from 2.64 to $2.4 \%$ under the same previous conditions. The major reason for the increase in percentage of bruised and cut tubers at lower speeds less than the optimum value is due to the increase in the number of tubers returning back on the chain towards the digging blade instead of going behind the machine after digging and cleaning operations. While the increase in percentage of bruised and cut tubers at higher forward speeds more than the optimum value is due to the increase in machine vibration causing blade floating action resulting in more bruised and cut tubers.

b-Effect of soil moisture content on Lifted, un-lifted, cut and bruised potato tubers:

Concerning the effect of soil moisture content on lifted, un-lifted, cut and bruised tubers. Results obtained in Fig (4) show that the soil moisture content of $11 \%$ is considered the proper value during digging potato which recorded the maximum lifted tubers and minimum un-lifted potato tubers of 92.4, 7.6; 96.5, 3.5and 97.5, 2.5 under digging depths of 22, 27 and $32 \mathrm{~cm}$, respectively. Fig (4) shows that, the decrease or increase of soil moisture content less or more than $11 \%$ leads to decrease lifted

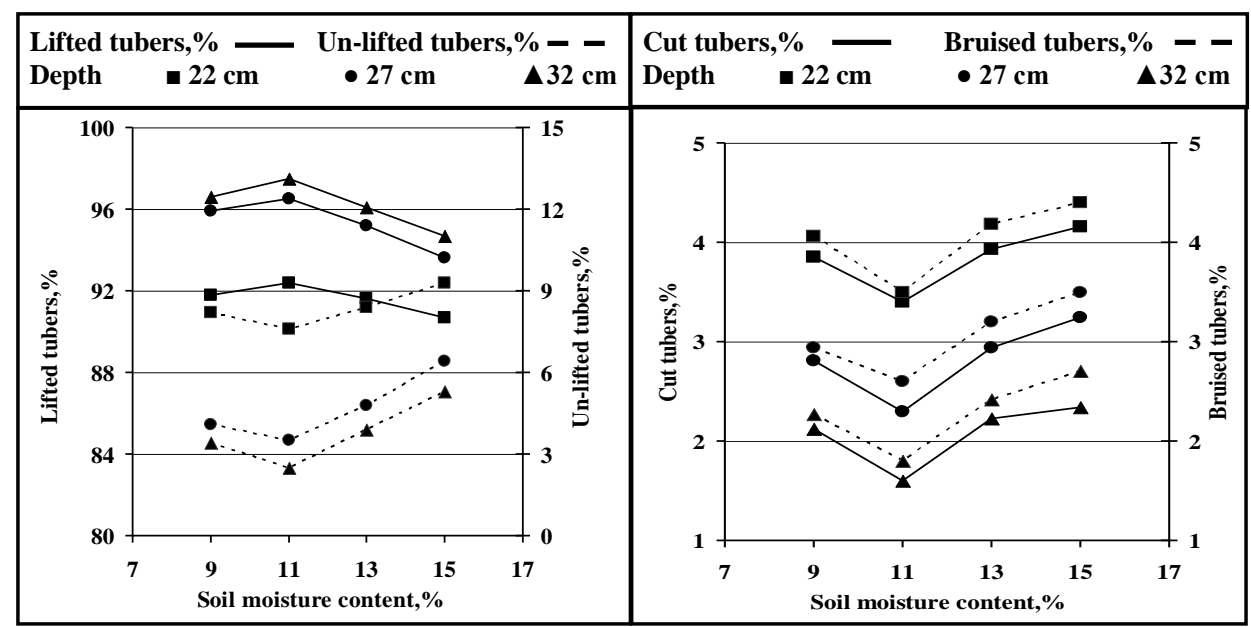

Fig (4): Effect of soil moisture content on mass of lifted, un-lifted, cut and bruised tubers under different digging depths, (forward speed $=2.2 \mathrm{~km} / \mathrm{h}$ ). 
tubers and increase un-lifted tubers under all experimental conditions due to the increase in soil catching force at lower moisture and increase elastic soil conditions at higher moisture which causing more rolling and slippage for potato digger. Relating to, the effect of soil moisture content on cut and bruised tubers, Fig.(4) shows that increasing soil moisture content, decreased cut and bruised tubers up to $11 \%$. Any further soil moisture content increase, up to $15 \%$ increased cut and bruised tubers. Increasing soil moisture content from 9 to $15 \%$, increased cut tubers from 3.85 to $4.16 \%$, from 2.81 to $3.24 \%$ and from 2.12 to $2.34 \%$ under digging depths of 22,27 and $32 \mathrm{~cm}$, respectively. Also, increasing soil digging depths of 22, 27 and $32 \mathrm{~cm}$, respectively. Also, increasing soil 4.4 $\%$, from 2.94 to $3.5 \%$ and from 2.27 to $2.7 \%$ under the same previous conditions.

\section{Damaged, total losses and digging efficiency:}

a- Effect of digger forward speed on damaged, total losses and digging efficiency:

Results in Fig (5) show the effect of forward speed on damage, total losses and digging efficiency. Concerning the effect of forward speed on damaged and total losses, Fig.(5) shows that increasing forward speed, decreased damaged tubers up to $2.2 \mathrm{~km} / \mathrm{h}$. Any further forward speed increase, up to $2.8 \mathrm{~km} / \mathrm{h}$, increased damaged tubers. While, increasing forward speed, decreased total losses up to $1.6 \mathrm{~km} / \mathrm{h}$. Any further forward speed increase, up to $2.8 \mathrm{~km} / \mathrm{h}$, increased total losses. Increasing forward speed from 0.9 to $2.8 \mathrm{~km} / \mathrm{h}$, decreased damaged tubers from 8.99 to $8 \%$, from 6.76 to $6.2 \%$ and from 5.07 to $4.5 \%$ under digging depths of 22, 27 and $32 \mathrm{~cm}$, respectively. While, increasing forward speed from 0.9 to 2.8 $\mathrm{km} / \mathrm{h}$, increased total losses from 14.39 to $17.3 \%$, from 8.46 to $11.9 \%$ and from 5.87 to $8.8 \%$ under the same previous conditions. Fig.(5) shows that increasing forward speed, increased digging efficiency up to $2.2 \mathrm{~km} / \mathrm{h}$. Any further forward speed increase, up to $2.8 \mathrm{~km} / \mathrm{h}$ decreased digging efficiency. Increasing forward speed from 0.9 to $2.8 \mathrm{~km} / \mathrm{h}$, increased digging efficiency from 91.01 to $92 \%$, from 93.24 to $93.8 \%$ and from 94.93 to $95.5 \%$ under the same previous. The major reason for the reduction in percentage of damaged and total tubers losses at lower speeds less than the optimum value is due to the increase in the number 
of tubers returning back on the chain towards the digging blade. These tubers are objected to more friction with the chain bars resulting in high percentage of damaged tubers. While the increase in percentage of damaged and total tubers losses at higher speeds more than the optimum value is due to the floating action of the blade which subjected potato tubers to more friction and rolling resulting in high damaged tubers.

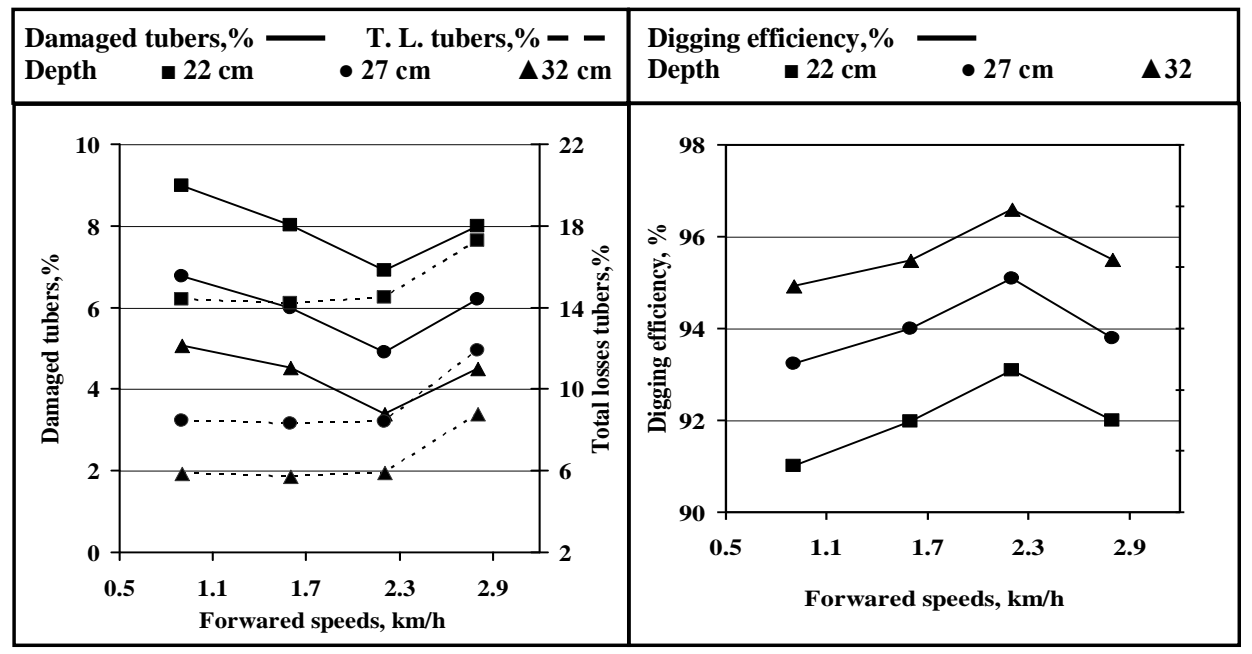

Fig (5): Effect of digger forward speed on mass of damaged, total losses tubers and harvesting efficiency under different digging depths, (S. M. C. = $11 \%$ ).

\section{b-Effect of soil moisture content on damaged, total losses and digging} efficiency:

Results in Fig (6) show the effect of soil moisture content on damaged tubers, total losses and digging efficiency. Concerning the effect of soil moisture content on damaged tubers and total losses. Fig.(6) shows that increasing soil moisture content, decreased damaged tubers and total losses up to $11 \%$. Any further soil moisture content increase, up to $15 \%$, increased damaged tubers and total losses. Increasing soil moisture content from 9 to $15 \%$, increased damaged tubers from 7.91 to $8.56 \%$, from 5.75 to $6.74 \%$ and from 4.39 to $5.04 \%$ under digging depths of 22 , 27 and $32 \mathrm{~cm}$, respectively. Also, increasing soil moisture content from 9 to $15 \%$, increased total losses from 16.11 to $17.86 \%$, from 9.85 to 13.14 $\%$ and from 7.79 to $10.34 \%$ under the same previous conditions. Fig. (6) 
shows that increasing soil moisture content increased digging efficiency up to $11 \%$. Any further soil moisture content increase, up to $15 \% 15 \%$, decreased digging efficiency from 92.09 to $91.44 \%$, from 94.25 to 93.26 $\%$ and from 95.61 to $94.96 \%$ under the same previous.

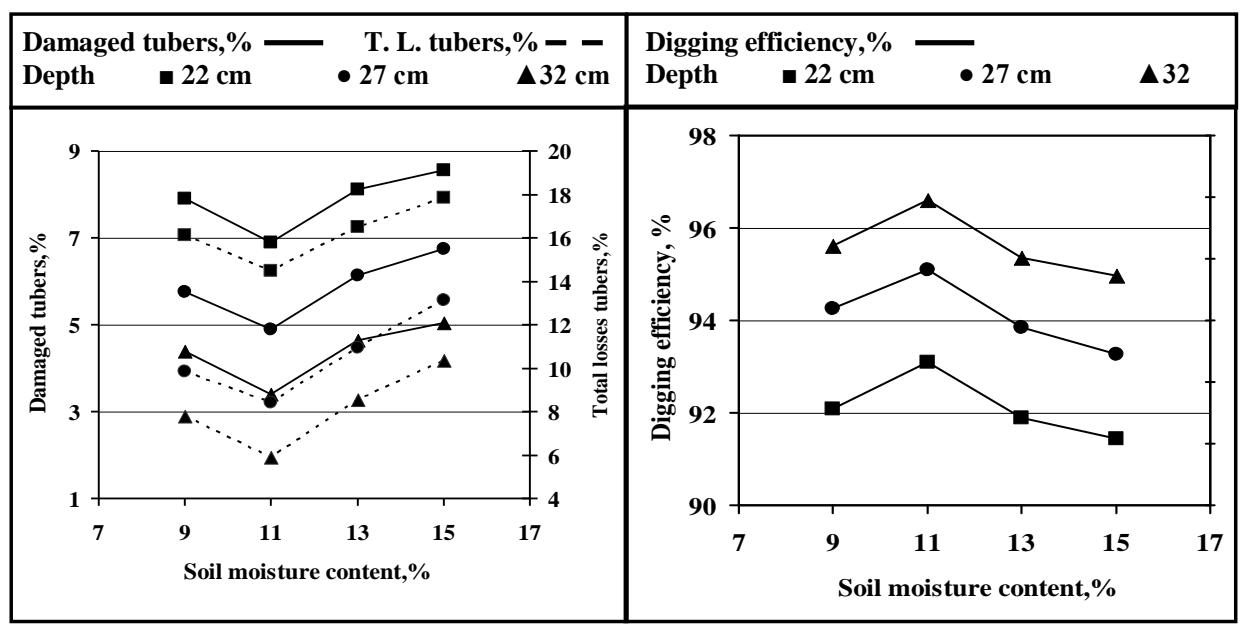

Fig (6): Effect of of soil moisture content on mass of damaged, total losses tubers and harvesting efficiency under different digging depths, $($ forward speed $=2.2 \mathrm{~km} / \mathrm{h}$ ).

\section{Power and energy requirements:}

\section{a- Effect of digger forward speed on power and energy requirements:}

Results in Fig (7) show the effect of digger forward speed on power and energy requirements. Concerning the effect of digger forward speed on power and energy requirements, Fig.(7) shows that increasing forward speed from 0.9 to $2.8 \mathrm{~km} / \mathrm{h}$, increased power values from 10.74 to 14.85 $\mathrm{kW}$, from 11.69 to $16.43 \mathrm{~kW}$ and from 12.64 to $17.69 \mathrm{~kW}$ under digging depths of 22, 27 and $32 \mathrm{~cm}$, respectively. While, increasing forward speed from 0.9 to $2.8 \mathrm{~km} / \mathrm{h}$, dcreased energy requirements values from 57.25 to $27.45 \mathrm{~kW} . \mathrm{h} / \mathrm{fed}$, from 63.53 to $31 \mathrm{~kW}$.h/fed and from 73.06 to $35.24 \mathrm{~kW} . \mathrm{h} / \mathrm{fed}$ under the same previous conditions.

\section{b-Effect of soil moisture content on power and energy requirements:}

Results in Fig (7) show the effect of soil moisture content on power and energy requirements. Concerning the effect of soil moisture content on power and energy requirements, Fig. (7) shows that increasing soil moisture content decreased power and energy requirements up to $11 \%$. 


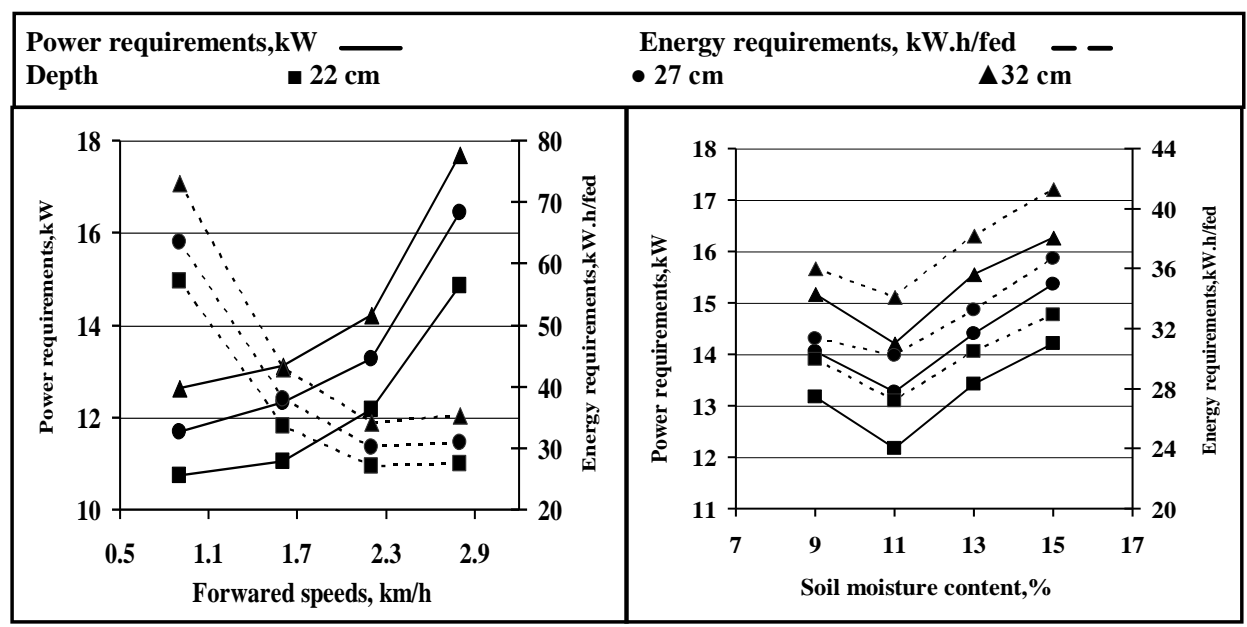

Fig (7): Effect of digger forward speed and soil moisture content on power and energy reqiurement under different digging depths.

Any further soil moisture content increase, up to $15 \%$, increased power and energy requirements. Increasing soil moisture content from 9 to 15 $\%$, increased power values from 13.18 to $14.22 \mathrm{~kW}$, from 14.06 to 15.36 $\%$ and from 15.17 to $16.27 \%$ under digging depths of 22,27 and $32 \mathrm{~cm}$, respectively. Also, Increasing soil moisture content from 9 to $15 \%$, increased energy requirements values from 29.97 to $32.92 \mathrm{~kW} . \mathrm{h} / \mathrm{fed}$ from 31.31 to $36.66 \mathrm{~kW} . \mathrm{h} /$ fed and from 36.03 to $41.29 \mathrm{~kW} . \mathrm{h} /$ fed under the same previous conditions.

\section{Criterion cost:}

\section{a. Effect of digger forward speed on criterion cost:}

Results in Fig (8) show the effect of digger forward speed on criterion cost Fig.(8) shows that increasing forward speed, decreased criterion cost up to $2.2 \mathrm{~km} / \mathrm{h}$. Any further forward speed increase, up to $2.8 \mathrm{~km} / \mathrm{h}$, increased criterion cost. Increasing forward speed from 0.9 to $2.8 \mathrm{~km} / \mathrm{h}$, increased criterion cost from 1031 to 1127 L.E./fed, from 663.4 to 790.5 L.E./fed and from 510.1 to 599.3 L.E./fed under digging depths of 22, 27 and $32 \mathrm{~cm}$, respectively.

\section{b. Effect of soil moisture content on criterion cost:}

Results in Fig (8) show the effect of soil moisture content on criterion 


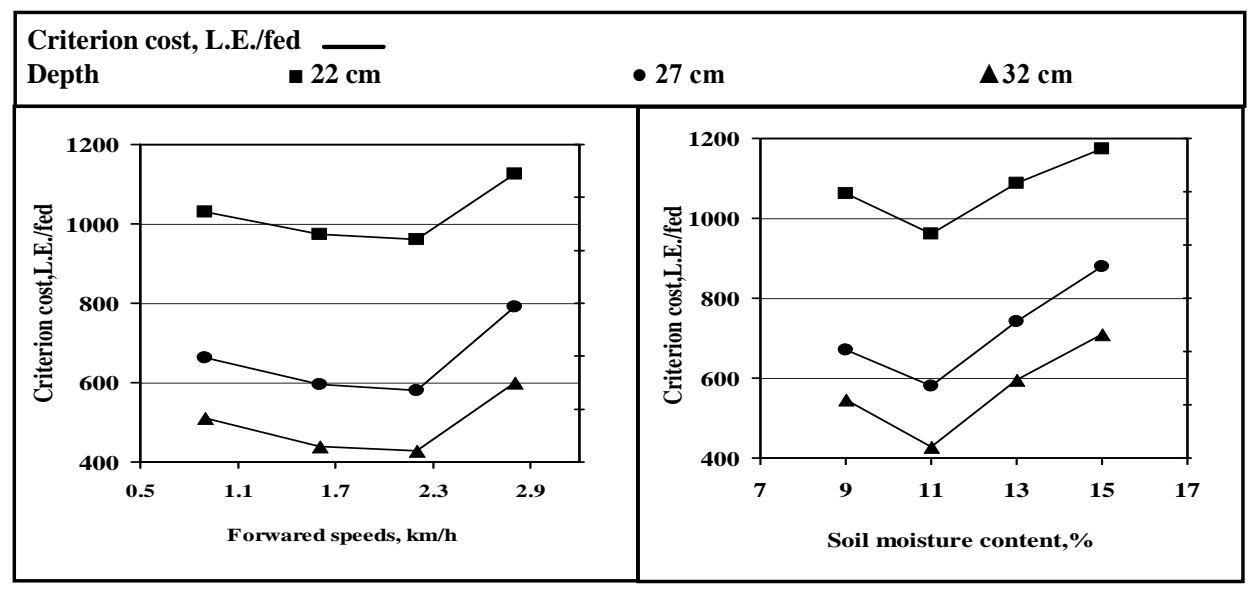

Fig (8): Effect of digger forward speed and soil moisture content on criterion cost under different digging depths.

cost. Fig.(8) shows that increasing soil moisture content, decreased criterion cost up to $11 \%$. Any further soil moisture content increase, up to $15 \%$, increased criterion cost. Increasing soil moisture content from 9 to $15 \%$, increased criterion cost from 1061.32 to 1173.59 L.E./fed, from 670.8 to880.37 L.E./fed and from 545.72 to 709.12 L.E./fed under digging depths of 22, 27 and $32 \mathrm{~cm}$, respectively.

\section{CONCLUSION}

A simplified potato digger was manufactured from locally available materials and evaluated under laboratory and field conditions. The main experiments were carried out at Al-Khattara farm, El-Sharkia governorate through the season of 2012 in sandy soil area of four feddans. Results showed that digging efficiency were maximum while both potato losses and digging cost were minimum under the following conditions:

- The proper digging depth is $27 \mathrm{~cm}$.

- The proper soil moisture content is $11 \%$.

- The proper forward speed is $2.2 \mathrm{~km} / \mathrm{h}$.

\section{REFERENCES}

Abd El-Magid, A. (1987): Determination of the basic operating parameters of potato harvesters. The byolurussian Inst. of Agric. Mech. Minisk. BCCR-USSR. (C. F. Afify and Mechail, 2000). 
Abdel -Aal, S. E.; M. S. EL-Shal; M. K. Abdel-Wahab and A. A. Abdel- Babry (2002): Development of a potato harvester suitable for Egyptian farms. Misr J. of Agric. Eng., 19 (3), July 2002: 643-656.

Abdel Maksoud S. E; M. M. Morad and H. A. Morghany (2004): Development of a combination unit for harvesting and gathering potatoes crop. Ph. D. Thesis, Department. of Agric. Eng., Faculty of Agric., Zagazing University.

Afify, M. K. and W. M. Mechail (2000): Development of a simple potato harvester. Misr J. of Agric. Eng., 17 (3), July 2000: 589604.

Amin, A. (1990): Mechanization for potato production on small farms. Ph. D. Thesis, Fac. of Agric., Mansoura Univ., Egypt.

Awady, M. N. (1978): Tractor and farm machinery. Text book, Faculty of Agriculture, Ain-Shams University. Pp: 164-167.

Awady, M. N; E. Y. Ghoneim and A. I. Hashish (1982): A critical comparison between wheat combine harvester under Egyptian conditions. R. S. No. 1920, Ain-Shams University. (FAO) J.

Hunt, D. (1983): Farm power and machinery management. $8^{\text {th }}$ Ed. Iowa state Univ., Press Ames, USA. Ames, Iowa, USA: 364-368.

Ibrahim, M. M; E. Amin and A. Farage (2008): Developing a multi purpose digger for harvesting root crops. Misr J. of Agric. Eng., 25 (4), October 2008: 1225-1239.

Kepner, R. A; K. Bainer and E. L. Barger (1982): Principles of farm machinery. $3^{\text {rd }}$ Ed., AVI Pub. Com. Inc., West port. 527 pp.

Mady, M. A. (1999): Mechanical harvesting of sweet potatoes. Misr J. of Agric. Eng., 16 (3), July 1999: 460-478.

Maughan, C. F. and A. I. Allam (1986): Evaluation of mechanical growing of sugar beet in Egypt. Agric. Res. Center, Sugar crop, Sakha Res. Station.

Younis, M. S. (1987): Mechanization of potato harvesting with minimum losses. Alexandria Journal of Agricultural Research, Egypt. 32 (3): 1-10.

Younis, M. S; M. I. Ghonimy and T. H. Mohamed (2006): Developed of potato digger. Misr J. of Agric. Eng., 23(2) pp: 292 - 313. 


\section{الملخص العـربـى}

\section{تصنيع وتقييم آلة محلية مبسطة لحصـاد محصـول البطاطس د. محمود مصطقى علي علي"}

نظر اً لأهمية محصول البطاطس حيث أنه يعتبر من المحاصيل ذات الأهمية الاقتصادية والتصديرية

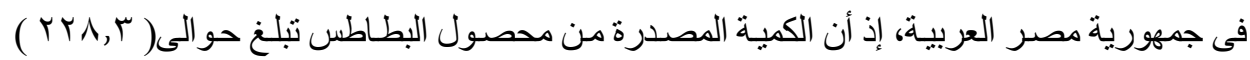

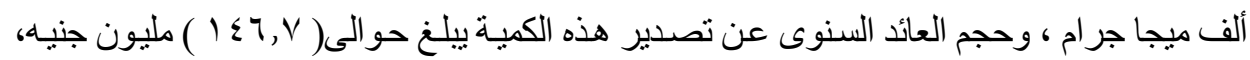

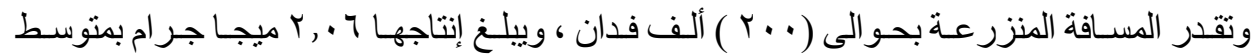

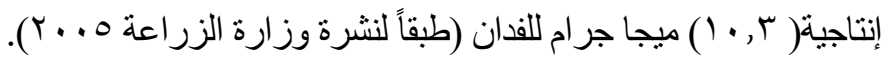

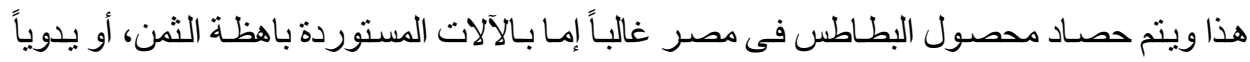
بالفأس ، و الطريقة البدويـة تؤدى إلى زيـادة نسبة الفقد والتلف فحى المحصول مع المسـاحات الكبيرة

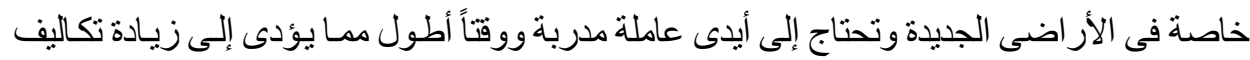

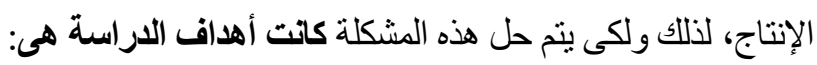
• تصنيع وتقييم آلة لحصاد خطو واحد من البطاطس.

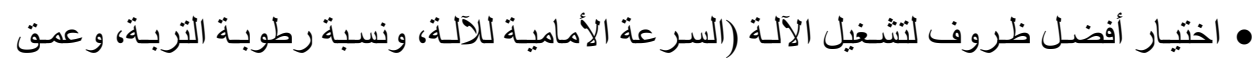

$$
\text { (التقليع). }
$$

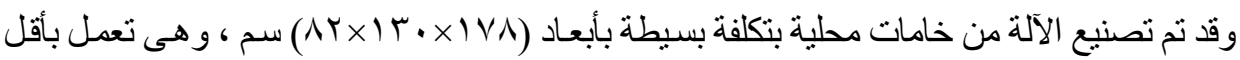
طاقة، و أقل تكاليف، و هى تنتكون مما بليى:

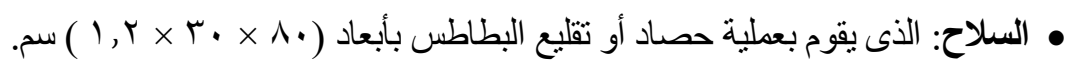

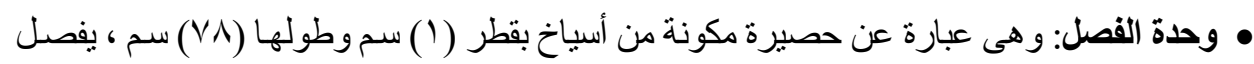
بين الأسياخ مسافة (ع) سم ، وهى تعمل على فصل التربة عن درنات البطاطس لتسقط نظيفة خلف

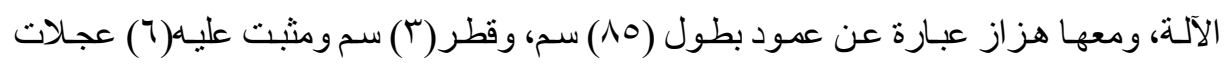

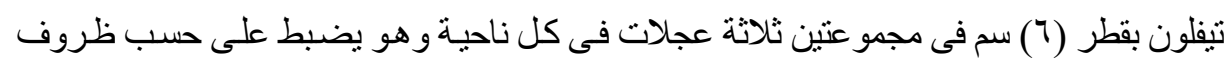
التشغيل و هو فى الأر اضي الرملية يكون حاملاً للحصيرة فقط.

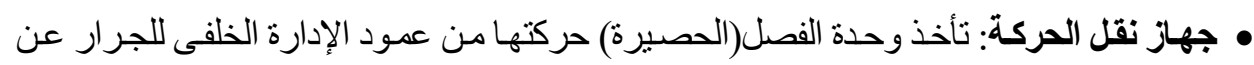
طريق (0) عجلات مسننة بأقطسار مختلفة وجنزيرين، وذلك لضبط سر عة وحدة الفصل حسب جركب الظروف المثلى للنتشغيل. ه شاسيه الآلة: و هو مكون من مجموعة من ألو اح الحديد سمكها (0, • ) سم، وقضبان من حديد علبة بأبعاد مختلفة لضمان متانة الآلة أثناء التشغيل. *أستاذ مساعد - قسم الهندسة الزراعية ـ كلية الزراعة - جامعة الزقازيق - مصر. 
وقد تم إجر اء التجربة فى مساحة أربعة أفذنة بمزر عـة كليـة الزر اعـة بالخطسارة في الموسم الزر اعي

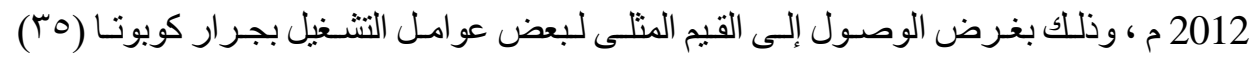

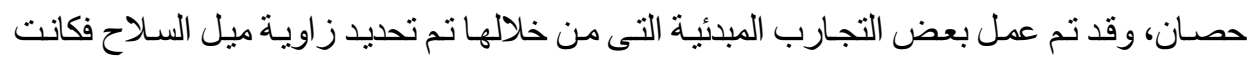

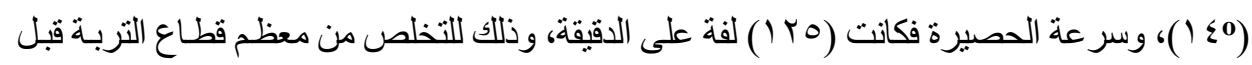

منتصف الحصبرة لتقليل القدرة المستهلكة فى التشغيل. واشتملت الاراسة علي المتغيرات التالية:

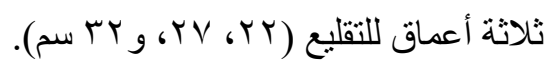

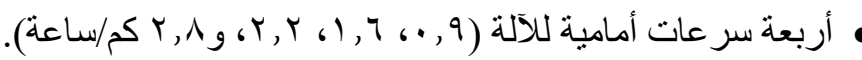

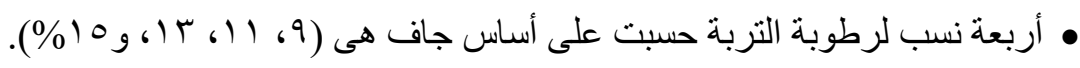
وقد تم تقييم المعاملات من حيث: السعة و الكفاءة الحقلية.

نسبة الدرنات المرفو عة، و المدفونة، و المقطو عة، و المخدوشة. نسبة الدرنات التالفة، و الفو اقد الكلية، وكفاءة التقليع. القدرة، و الطاقة المستهلكة. التكاليف الحدية لتشغيل آلة التقليع. وقد أظهرت النتائج ما يلى:

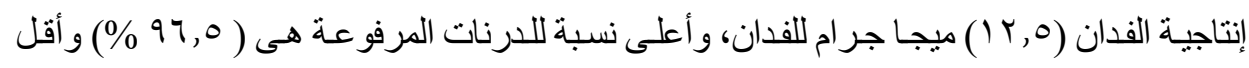

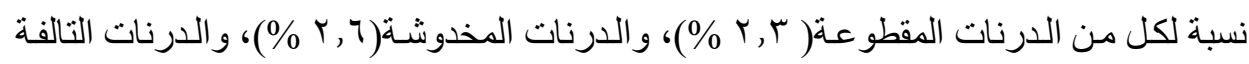

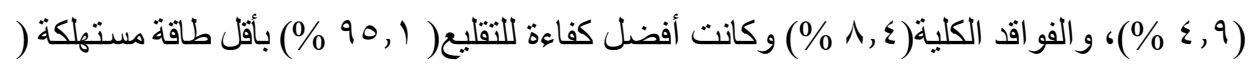

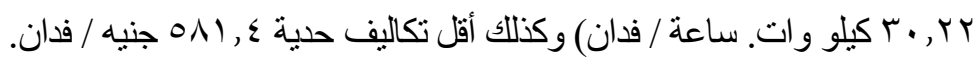
ومن خلال النتائج تم التوصل إلى التوصيات الآتية: عمث التقليع (rV) مدم). نسبة رطوبة التربة (1 ( \% على أساس جاف). •السر عة الأمامية للآلة (Y, r كم/ساعة). 